\title{
JOURNAL OF INDONESIAN APPLIED ECONOMICS
}

\section{TELAAH KRITIS KEBIJAKAN PENANGGULAN KEMISKINAN DALAM TINJAUAN KONSTITUSI}

\author{
Multifiah \\ Fakultas Ekonomi \& Bisnis Universitas Brawijaya
}

\begin{abstract}
This paper aims to examine several poverty alleviation programs which have been done for periods of time and evaluate the programs constitutionally in the framework of UUD 1945. The study finds that there are many programs held by the government, yet their mostly obstacles are overlapping objectives and the problem of corruption and collusion. Moreover, the absence of clear guidance makes the conditions worse. UUD 1945 focuses in how to reduce poverty through basic needs fulfillment such as educations, health, and social safety net, which are needed as key ingredients to succeed sustainable poverty alleviation programs.
\end{abstract}

Keywords: poverty alleviation programs, UUD 1945.

\section{A. LATAR BELAKANG}

Kemiskinan merupakan masalah utama pembangunan yang sifatnya kompleks dan multi dimensional. Persoalan kemiskinan bukan hanya berdimensi ekonomi tetapi juga sosial, budaya, politik bahkan juga ideologi. Secara umum kondisi kemiskinan tersebut ditandai oleh kerentanan, ketidakberdayaan, keterisolasian, dan ketidakmampuan untuk menyampaikan aspirasi dan kebutuhannya.

Pengalaman penanggulangan kemiskinan pada masa lalu telah memperlihatkan berbagai kelemahan, antara lain: (i) masih berorientasi kepada pertumbuhan makro tanpa memperhatikan aspek pemerataan, (ii) kebijakan yang bersifat sentralistik, (iii) lebih bersifat karikatif daripada transformatif, (iv) memposisikan masyarakat sebagai obyek daripada subyek, (v) orientasi penanggulangan kemiskinan yang cenderung karikatif dan sesaat daripada produktivitas yang berkelanjutan, serta (vi) cara pandang dan solusi yang bersifat generik terhadap permasalahan kemiskinan yang ada tanpa memperhatikan kemajemukan yang ada. Karena begitu beragam sifat tantangan yang ada, maka penanganan persoalan kemiskinan harus menyentuh dasar sumber dan akar persoalan yang sesungguhnya, baik langsung maupun tak langsung.

Masih tingginya angka kemiskinan di Indonesia menunjukan bahwa program-program penanggulangan kemiskinan selama ini perlu dievaluasi baik ditingkat nasional maupun daerah. Beberapa contoh program penanggulangan kemiskinan di tingkat nasional diantaranya adalah program bantuan Beras untuk Keluarga Miskin (Raskin) dalam bidang pangan, Asuransi Kesehatan Keluarga Miskin (Askeskin) untuk bidang kesehatan, dan Bantuan Langsung Tunai (BLT). Sedangkan level propinsi, Jawa Timur memiliki program kemiskinan yang pernah dilaksanakan yaitu Gerakan Terpadu Pengentasan Kemiskinan (Gardutaskin) yang pernah dilaksanakan, Program Aksi Mengatasi Dampak Kenaikan Bahan Bakar Minyak (PAM DKB), 
yang kemudian diganti dengan Jaring Pengaman Ekonomi Sosial(JPES). Bahkan, satu keluarga miskin bisa mendapatkan bantuan dari beberapa program penanggulangan kemiskinan oleh pemerintah.

Dengan banyaknya program penanggulangan kemiskinan tersebut, tetapi jumlah penduduk miskin masih tinggi, maka diperlukan evaluasi secara terintegrasi. Salah satu poin utama evaluasi tersebut adalah memahami kembali makna dan nilai-nilai kemiskinan serta tujuan nasional seperti yang tercantum dalam Undang-Undang Dasar negara 1945. Dengan pemahaman yang sama tentang kedua hal tersebut maka formulasi kebijakan penanggulangan kemiskinan dapat terarah dan terencana dengan baik. Oleh karena itu, kajian mengenai reformulasi strategi penanggulangan kemiskinan dalam tinjauan konstitusi perlu dan penting untuk dilakukan. Berdasarkan latar belakang di atas, tujuan dari kajian ini adalah untuk 1). Mengevaluasi berbagai program penanggulangan kemiskinan yang telah dilakukan selama ini; dan 2). Memformulasikan strategi penanggulangan kemiskinan berdasarkan tinjauan konstitusi.

\section{B. KAJIAN TEORITIS}

\section{Pembangunan dan Kemiskinan: Suatu Korelasi}

Pada dasarnya pembangunan ekonomi bertujuan untuk mewujudkan suatu kemakmuran. Padahal kemakmuran itu sendiri berdimensi sangat luas dan lebih bersifat abstrak. Dari sisi pemikiran, hubungan antara pembangunan ekonomi dan kemakmuran telah dikaji salah satunya oleh aliran neo klasik. Dalam neo klasik pembangunan dititik beratkan untuk mewujudkan pertumbuhan ekonomi yang tinggi dengan peningkatan pendapatan yang sebesar-besarnya.

Namun demikian, mengutip pernyataan Alfred Marshall yang mengemukakan bahwa para ekonomi neo klasik merupakan orang-orang yang sederhana, bersahaja, dan selalu prihatin atas berlangsungnya keadaan ketimpangan dalam pembagian kekayaan antara anggota-anggota masyarakat. Kutipan Alfred Marshall tersebut adalah sebagai berikut (Mubyarto, 1995):

The find is that nearly all the founders of modern economics were man of gentle and sympathetic temper, touched with enthusiam of humanity. They cared little for wealth for themselves; they cared much for its wide diffusion among the masses of the people. They opposed antisocial monopolies however powerful They were without exception devoted to the doctrine that the wellbeing of the whole people should he the ultimate goal of all private effort and all public policy. But they were strong in courage and caution, they appeared cold, because they would not assume the responsibility of advocating rapid advance on untried paths, for the safety of which the only guarantees offered were the confident hopes of men whose imaginations were eager hut not steadied by knowledge nor disciplined by hard thought.

Tetapi akhir-akhir ini sejumlah ekonom tidak hanya melihat pembangunan sebatas kepada peningkatan pertumbuhan saja. Pembangunan dilihat dari dimensi yang jauh lebih luas, diantaranya dengan melihat penurunan tingkat kemiskinan sebagai salah satu indikator keberhasilan pembangunan.

Meier (1976) menyebutkan bahwa pembangunan ekonomi didefinisikan sebagai 'proses' yang melalui proses ini pendapatan riil per kapita sebuah negara meningkat untuk periode jangka 
panjang dengan syarat bahwa sejumlah orang yang hidup di bawah 'garis kemiskinan mutlak' tidak naik dan distribusi pendapatan tidak semakin timpang. Selain itu suatu kemajuan pembangunan dapat diukur secara lebih berimbang dengan melihat penurunan tingkat kemiskinan daripada peningkatan lebih lanjut kekayaan orang-orang yang sudah makmur (Sen, 2000).

Menurut Swasono (2002), pembangunan adalah memberdayakan (empowering) rakyat atau meningkatkan produktivitas rakyat dan menghentikan peminggiran atau pelumpuhan (disempowering) rakyat, merubah secara struktural posisi rakyat miskin yang dipersepsikan sebagai beban pembangunan menjadi aset pembangunan. Pembangunan ekonomi yang menggusur rakyat, mendorong disintegrasi sosial bangsa dan memperpuruk negara merupakan suatu default of development Sebab pembangunan ekonomi pada dasarnya untuk menggusur kemiskinan, bukan menggusur orang miskin (to remove poverty, not to remove the poor).

Memang tidak bisa dipungkiri bahwa pembangunan telah memberikan sumbangan yang tidak sedikit terhadap kemakmuran umat manusia. Namun juga tidak bisa dibantah bahwa pembangunan disisi lain justru menciptakan kemunduran yang luar biasa dalam kehidupan manusia. Apabila planet yang dihuni oleh manusia ini dikapling berdasarkan luas wilayahnya, maka kemiskinan dan pengangguran memiliki area yang jauh lebih luas daripada area kemakmuran. Dalam dimensi yang lebih luas, pembangunan didefinisikan sebagai sebuah kebebasan bagi seluruh masyarakat untuk melaksanakan sesuatu sepanjang tidak bertentangan dengan norma dan aturan hukum yang berlaku (Sen, 1999).

Dengan definisi-definisi pembangunan yang disebutkan diatas, tersirat bahwa tidak ada hubungan positif antara tingkat pertumbuhan ekonomi dengan tingkat kemiskinan. Tetapi suatu negara yang memiliki tingkat pendapatan per kapita yang tinggi belum tentu tingkat kemiskinan penduduknya akan rendah. Demikian juga sebaliknya bila tingkat kemiskinan di suatu negara tersebut sangat tinggi bukan berarti tingkat pendapatan perkapitanya lebih rendah daripada negara yang memiliki tingkat kemiskinan rendah. Hal tersebut tergantung dari proses perencanaan pembangunan yang dijalankan di masing-masing negara tersebut.

Pola hubungan antara pertumbuhan ekonomi yang cukup terkenal selama ini berdasarkan dan Hipotesis Kuznets dengan model kurva U terbaliknya. Hipotesis Kuznets tersebut menunjukkan adanya hubungan negatif antara tingkat pertumbuhan ekonomi dengan tingkat kemiskinan. Sebaliknya hubungan pertumbuhan ekonomi dengan tingkat kesenjangan ekonomi adalah positif. Selain itu Hipotesis Kuznets juga menyebutkan dalam jangka pendek ada korelasi positip antara pertumbuhan pendapatan perkapita dengan kesenjangan pendapatan. Namun dalam jangka panjang hubungan keduanya menjadi korelasi yang negatif. Artinya dalam jangka pendek meningkatnya pendapatan akan diikuti dengan meningkatnya kesenjangan pendapatan, namun dalam jangka panjang peningkatan pendapatan akan diikuti dengan penurunan kesenjangan pendapatan. Kuznets juga menyimpulkan bahwa pola hubungan yang positif kemudian menjadi negatif, rnenunjukkan terjadi proses evolusi dan distribusi pendapatan dari masa transisi suatu ekonomi pedesaan (rural) ke suatu ekonomi perkotaan (urban) atau ekonomi industri.

Akan tetapi juga tidak dapat disimpulkan secara langsung bahwa pertumbuhan ekonomi yang pesat selalu disertai kemerosotan dalam tingkat kemiskinan dan pembagian pendapatan. Hal itu tergantung dan kondisi khusus yang terdapat di masing-masing negara berkembang serta kebijaksanaan ekonomi khusus yang ditempuh oleh berbagai negara tersebut (Basri, 1995). 


\section{Definisi dan Ukuran kemiskinan}

Menurut Arsyad (1992), kemiskinan dapat diamati sebagai kondisi anggota masyarakat yang tidak atau belum ikut serta dalam proses perubahan karena tidak mempunyai kemampuan, baik kemampuan dalam pemilikan faktor produksi maupun kualitas faktor produksi yang memadai sehingga tidak mendapatkan manfaat dan hasil proses pembangunan. Kemiskinan dalam penelitian yang dilakukan (Ngatimin, 2001) didefinisikan sebagai kurangnya pendapatan untuk memenuhi kebutuhan hidup yang pokok. Kemiskinan dipandang sebagai "ketidaksamaan kesempatan untuk mengakumulasikan kekuatan basis sosial." Basis kekuatan sosial meliputi (tidak terbatas pada): modal yang produktif, atau assets (misalnya tanah, perumahan, peralatan, kesehaan, dan lainlain); sumber-sumber keuangan (income dan kredit yang memadai); organisasi sosial dan politik yang dapat digunakan untuk mencapai kepentingan bersama (partai politik, sindikat, koperasi, dan lain-lain).

Kemiskinan muncul sebagai akibat dan adanya situasi ketidakadilan, ketimpangan serta ketergantungan dalam struktur masyarakat. Chambers (1995) mengatakan bahwa inti dari masalah kemiskinan ini sebenarnya terletak pada apa yang disebut dengan "deprivation trap" atau perangkap kemiskinan, dimana secara rinci deprivation trap terdiri dan lima unsur sebagai penyebab kemiskinan, yaitu: ketidakberdayaan (powerlesness), kerawanan, ketidaksempurnaan pasar, keterbelakangan, ketertinggalan, kekurangan modal atau kerentanan (vulnerability), kelemahan fisik (physical weakness), kemiskinan (poverty) dan isolasi (isolation).

Pada umumnya ada dua macam ukuran kemiskinan yang sering digunakan yaitu kemiskinan absolut dan kemiskinan relatif. Kemiskinan absolut diartikan sebagai suatu keadaan dimana tingkat pendapatan absolut dan suatu orang tidak mencukupi untuk memenuhi kebutuhan pokoknya, sepenti pangan, sandang, pemukiman, kesehatan dan pendidikan. Besarnya atau dimensi masalah kemiskinan absolut tercermin dari jumlah penduduk yang tingkat pendapatan atau tingkat pemukiman, kesehatan dan pendidikan. Besarnya atau dimensi masalah kemiskinan absolut tercermin dan jumlah penduduk yang tingkat pendapatan atau tingkat konsumsinya berada di bawah ‘tingkat minimum' yang telah di tetapkan diatas (Basri 1995).

Sedangkan konsep kemiskinan relatif bersifat lebih dinamis daripada konsep kemiskinan absolut. Karena menurut konsep ini kemiskinan lebih banyak ditentukan oleh keadaan sekitarnya, daripada lingkungan yang bersangkutan (Oktaviani, 2001). Oleh sebab itu, dengan konsep ini kemiskinan akan tetap selalu ada berdasarkan ketimpangan yang terjadi antara golongan atas dengan golongan bawah di dalam suatu lingkungan tersebut.

Ukuran kemiskinan yang dianut oleh negara negara dan standar Bank Dunia, ternyata secara empiris kadang kadang kurang bisa menjelaskan fenomena kemiskinan. Terutama, membandingkan kemiskinan dengan kesejahteraan. Tidak semua kemiskinan identik dengan ketidaksejahteraan, demikian juga tingkat pendapatan yang tinggi, belum mencerminkan tingkat kesejahteraan yang tinggi. Sen poverty index (SPI) yang merupakan formula yang digunakan untuk mengukur indeks kemiskinan, ternyata tidak mampu mengukur tingkat kesejahteraan. SPI yang lebih mendasarkan pada poverty head account ratio yang diambil dari penyebaran pendapatan per kapita (koefisien Gini) ternyata hanya mengukur kemiskinan dari tingkat pendapatan. Apakah tingkat pendapatan tersebut mencerminkan kemiskinan? Jawaban pertanyaan ini bisa betul dan bisa tidak, tergantung bagaimana pola konsumsi, pola kehidupan serta faktor jaminan keamanan akan kehidupan dari setiap negara kepada penduduknya. 
Dalam kasus Indonesia, secara umum memakai standar pengukuran kemiskinan dari standar Bank Dunia. Namun beberapa pendekatan atau tepatnya penyesuian dilakukan oleh Biro Pusat Statistik (BPS) dalam menghitung batas miskin. Kajian utama didasarkan pada ukuran pendapatan (ukuran finansial), dimana batas kemiskinan dihitung dan besarnya rupiah yang dibelanjakan per kapita sebulan untuk memenuhi kebutuhan minimum makanan dan bukan makanan. Untuk kebutuhan makanan digunakan patokan 2100 kalori perhari. Sedangkan pengeluaran kebutuhan minimum bukan makanan meliputi pengeluaran untuk perumahan, sandang, serta aneka barang dan jasa. Pengeluaran bukan makanan ini dibedakan antara perkotaan dan pedesaan.

Sedangkan ukuran lain dari kemiskinan berdasarkan Pedoman Umum P2KP (2002) dinyatakan secara lebih umum. P2KP mendefinisikan bahwa rumusan kemiskinan setempat yang disepakati oleh warga, termasuk di dalamnya adalah masyarakat yang telah lama miskin, masyarakat yang penghasilannya merosot, dan tidak berarti akibat inflasi, serta masyarakat yang kehilangan sumber nafkahnya dikarenakan krisis ekonomi.

\section{Kemiskinan dalam Tinjauan UUD 45}

Seperti yang tertulis pada Pembukaan Undang-undang Dasar 1945:

...membentuk suatu Pemerintah Negara Indonesia yang melindungi segenap bangsa Indonesia dan seluruh tumpah darah Indonesia, memajukan kesejahteraan umum, mencerdaskan kehidupan bangsa dan ikut melaksanakan ketertiban dunia yang berdasarkan kemerdekaan, perdamaian abadi dan keadilan sosial....

Inilah tujuan nasional yang menjadi landasan awal penanggulangan kemiskinan di Indonesia. Tentunya dalam menanggulangi kemiskinan harus diketahui dahulu makna kemiskinan dan juga kesejahteraan. Sehingga awal dan akhir dari tujuan yang ingin dicapai dapat diketahui.

\section{Makna Kemiskinan Menurut UUD 1945}

Kemiskinan mempunyai makna yang sangat luas hal ini yang menyebabkan makna kemiskinan mengalami koreksi tiap waktu. Secara konvensional kemiskinan dimaknai dengan pendapatan yang kurang dikarenakan distribusi kekayaan yang tidak merata yang menyebabkan seseorang atau keluarga tidak mampu memenuhi kebutuhan dasar untuk kehidupan sehari-hari. Parameter untuk mengetahui pendapatan yang kurang adalah pengeluaran rumah tangga yang amat rendah. Dengan pengertian kemiskinan ini tentunya yang harus dilakukan pemerintah mengusahakan agar pendapatan dari seseorang dapat ditingkatkan sehingga memenuhi kebutuhan dasar untuk kehidupan sehari-hari.

Makna konvensional kemiskinan tersebut kemudian mengalami koreksi. Kemiskinan tidak hanya menyangkut kesenjangan pendapatan. Pada pertengahan 1980-an muncul rumusan definisi baru: "Kemiskinan harus dimaknai: orang, keluarga, dan sekelompok masyarakat yang memiliki keterbatasan sumber daya material, sosial, dan budaya, sehingga menghalangi mereka untuk dapat hidup layak menurut ukuran paling minimal di suatu negara tempat mereka bermukim" (Komisi Eropa, 1984 dalam Alhumami, 2009).

Makna kemiskinan menjadi perdebatan dikalangan sarjana sehingga kemiskinan tidak lagi bermakna kesenjangan pendapatan atau tidak meratanya distribusi kekayaan, tetapi lebih ditekankan pada pemerataan kesempatan untuk mendapatkan hak-hak dasar, yang dimulai sejak manusia lahir. Pergeseran makna kemiskinan ini jelas terlihat dalam laporan Bank Dunia, Equity 
and Development (2006 dalam Alhumami, 2009), membahas isu pembangunan sosial dengan pendekatan lintas ilmu dan analisis multidimensional.

Pergeseran makna kemiskinan tersebut tentunya menjadikan parameter kemiskinan menjadi berbeda dari sebelumnya. Sebelumnya kemiskinan yang hanya dilihat dari kurangnya pendapat yang dapat diketahui dari pengeluaran rumah tangga yang amat rendah, untuk selanjutnya hal ini tidak dapat dipakai untuk melihat tingkat kemiskinan.

Kemiskinan oleh Bappenas (2005) didefinisikan sebagai kondisi di mana seseorang atau sekelompok orang, laki-laki dan perempuan, tidak terpenuhi hak-hak dasarnya untuk mempertahankan dan mengembangkan kehidupan yang bermartabat. Definisi kemiskinan ini beranjak dari pendekatan berbasis hak yang mengakui bahwa masyarakat miskin, baik laki-laki maupun perempuan, mempunyai hak-hak dasar yang sama dengan anggota masyarakat lainnya. Kemiskinan tidak lagi dipahami hanya sebatas ketidakmampuan ekonomi, tetapi juga kegagalan pemenuhan hak-hak dasar dan perbedaan perlakuan bagi seseorang atau sekelompok orang, laki-laki dan perempuan, dalam menjalani kehidupan secara bermartabat. Definisi kemiskinan oleh pemerintah ini sebenarnya sudah termasuk mencakup untuk menanggulangi krisis multidimensi. Kemiskinan diartikan sebagai pelanggaran hak dari seseorang atau kelompok masyarakat. Hak-hak dari setiap warga Negara Indonesia ini telah tertuang dalam UUD 1945.

\section{METODE PENELITIAN DAN ANALISIS DATA}

\section{Jenis Penelitian}

Jenis penelitian yang digunakan adalah penelitian deskriptif. Menurut Indriantoro dan Supomo (2002) penelitian deskriptif merupakan penelitian terhadap masalah-masalah berupa fakta-fakta saat ini dari suatu populasi. Tujuan penelitian deskriptif adalah untuk membuat deskripsi, gambaran atau lukisan secara sistematis, faktual, dan akurat mengenai fakta-fakta, sifat-sifat serta hubungan antar fenomena yang diselidiki.

\section{Jenis dan Sumber Data}

Jenis data yang digunakan dalam penelitian ini adalah data sekunder dan data primer. Data sekunder yaitu data yang diperoleh secara tidak langsung dari objek penelitian. Data sekunder merupakan data yang tidak diperoleh dari sumbernya langsung, melainkan sudah dikumpulkan oleh pihak lain. Metode pengumpulan data dilakukan dengan teknik dokumentasi, yaitu pengumpulan data baku yang diperoleh pada Instansi atau Organisasi yang ada, baik pemerintah maupun swasta. Sumber data sekunder berasal dari beberapa instansi yang berwenang dalam pengeluaran data yaitu, Badan Pusat Statistik dan intansi-intansi terkait serta berbagai hasil penelitian yang berkaitan dengan kajian ini.

Sedangkan data primer diperoleh langsung melalui depth interview atau wawancara secara mendalam oleh peneliti. Dalam melakukan wawancara tersebut peneliti akan menggunakan pedoman interview yang telah disusun sebelumnya sehingga akan menghasilkan interview yang terarah sesuai dengan tujuan penelitian.Selain itu peneliti juga akan melakukan focus group discussion dengan bebera pakar yang berkaitan dengan penelitian ini 


\section{Metode Analisis}

Dalam upaya mereformulasi strategi penanggulangan kemiskinan dalam tinjauan konstitusi, peneliti akan menggunakan metode penelitian eksploratif. Jenis penelitian ini berusaha mencari ide-ide atau hubungan-hubungan yang baru. Metode ini sangat fleksibel dalam pencarian gagasan dan ide serta petunjuk mengenai kondisi dan situasi yang berkaitan dengan permasalahan yang dikaji sehingga dapat memformulasikan kebijakan atau strategi yang tepat.

Dengan metode penelitian ini, peneliti akan menggali permasalahan yang berkaitan dengan penanggulangan kemiskinan. Langkah pertama yang perlu dilakukan adalah mengumpulkan semua dokumen yang berkaitan dengan program-program penanggulangan kemiskinan termasuk aspek keberhasilan dan kegagalannya. Selanjutnya mengidentifikasi permasalahan mulai dari gejala sampai masalah yang mendasar. Setelah proses identifikasi selanjutnya peneliti akan mengklasifikasikan masalah dan mendesain kebijakan perencanaan pembangunan ekonomi yang tepat yang diarahkan pada formulasi strategi penanggulangan kemiskinan.

\section{HASIL DAN PEMBAHASAN}

\section{Program Penanggulangan Kemiskinan: Tinjauan di Berbagai Negara}

Kemiskinan merupakan penyakit kronis yang menjangkit hampir semua negara di dunia. Karena itu sudah banyak hal yang dilakukan oleh berbagai pihak dalam rangka memutus lingkaran setan kemiskinan tersebut, yang harus diketahui dan dipelajari tingkat keberhasilannya.

\section{Peran micro finance dalam program pengentasan kemiskinan di Malaysia}

Malaysia merupakan negara multirasial yang dapat dianggap telah berhasil dalam pembangunan ekonominya. Malaysia merancang program pembangunannya sejalan dengan program untuk mengurangi jumlah penduduk miskin dan memperkecil angka ketimpangan pendapatan, tanpa mengabaikan aspek keberagaman yang juga berhasil dihimpunnya dalam suatu harmoni.

Secara konstitusi program pengentasan kemiskinan yang diusung oleh Malaysia di tuangkan dalam kebijakan nasional inti yang secara ideologi mengacu pada pemikiran bahwa terwujudnya pertumbuhan ekonomi yang mapan tidak lepas dari usaha pemerintah untuk mensejahterakan rakyatnya (dalam hal ini mengurangi jumlah penduduk miskin dan distribusi pendapatan yang merata). Kebijakan ini-New Economic Policy (NEP) dan National Development Policy (NDP)- bersandar pada filosofi bahwa tujuan dari pembangunan negara adalah kesatuan negara (national unity). Tujuan tersebut dapat dicapai dengan program poverty alleviation dan restrukturisasi masyarakat Malaysia.

NEP tercatat sebagai program pengentasan kemiskinan yang sukses dicanangkan oleh pemerintahan Malaysia dimana program ini telkah mengurangi angka kemiskinan di Peninsular dari 49,3\% di tahun 1970 menjadi 15\% di tahun 1990. Selanjutnya di Sabah dan Sarawak berturutturut 58,3\% dan 56,5\% ditahun 1976 menjadi 34,3\% dan 21\% ditahun 1990, serta di beberapa wilayah lain di Malaysia, sehingga secara nasional angka kemiskinan Malaysia menurun dari 42,4\% ditahun 1976 menjadi 17,1\% tahun 1990 dan 9,6\% ditahun 1995 . 
Capaian yang sungguh luar biasa ini tidak lepas dari peran micro finance program yang merupakan bagian dari NEP. Program ini secara garis besar merupakan replikasi dari Grameen Bank's yang tujuan utamanya adalah memberikan pinjaman dari pintu ke pintu (doorsteps) dalam rangka menjangkau masyarakat miskin yang tidak tersentuh oleh lembaga keuangan formal seperti bank, credit union, koperasi, dan sebagainya. Micro finance memberikan kredit sekitar RM 10,000 dan sebagian besar digunakan untuk mendanai usaha kecil, pinjaman untuk pertanian dan lain-lain yang bersifat mengurangi kemiskinan.

Dengan adanya program kredit untuk masyarakat kecil ini Malaysia, dalam tiga dekade terakhir, mampu memiliki prestasi mengesankan dalam aspek penanggulangan kemiskinan, terutama dalam hal income generation, pemeliharaan kesehatan, dan pendidikan. Meskipun secara income perkapita, Malaysia belum termasuk negara dengan golongan penduduk berpendapatan tinggi, namun dilihat dari jumlah penikmat teknologi terkini, Malaysia cukup dapat dianggap sangat berhasil. Sebagai gambaran, jumlah komputer/orang yaitu 147 PC per 100 orang, dan pengguna internet mencapai angka 320 pengguna per 1000 orang. Sebagai tambahan, Malaysia juga memiliki angka buta huruf yang rendah, yaitu 12\% (1997) dan 60\% penduduknya tinggal di perkotaan. Akses terhadap basic needs seperti di atas lah yang membuat pertumbuhan ekonomi Malaysia boleh dikatakan mapan. Aliran modal masuk turut mempercepat terciptanya suatu kondisi perekonomian yang kondusif dalam pengentasan kemiskinan.

Akses terhadap micro credit bisa jadi alasan yang masuk akal dalam rangka mencapai angka fantastis di atas. Akses terhadap kredit sangat krusial karena dapat membuat masyarakat miskin memberdayakan pengetahuan dan skill-nya dengan membeli aset untuk menambah penghasilan mereka. Satu alasan terpenting berkenaan dengan keberhasilan micro finance program dalam mengentaskan kemiskinan adalah kebijakan pemerintah yang kondusif dan mendukung program tersebut.Sehingga baik lender maupun borrower dapat mengoptimalkan peran mereka masing-masing.

\section{Mahasastra Employment Guarantee Scheme di India}

Program ini secara umum merupakan program pengentasan kemiskinan melalui pemberian jaminan hidup bagi masyarakat miskin, bahwa mereka dijamin akan dapat memenuhi kebutuhan pokoknya. Pemikiran ini berawal dari kebanyakan masyarakat India yang masih mengandalkan musim dalam bertani. Sehingga ada kalanya mereka tidak dapat memenuhi kebutuhan mereka sehari-hari dikarenakan pekerjaan yang seasonal dan risky. Pemerintah, melalui program ini berusaha meminimalisir resiko tersebut dengan menjamin bahwa mereka akan mendapatkan upah setara dengan upah minimum bila mereka bekerja pada pemerintah dalam hitungan jam tertentu per harinya. Dengan kata lain, siapa yang ingin mendapatkan pekerjaan dengan upah setara dengan upah minimum tersebut, pemerintah akan menyediakan pekerjaan itu. Mereka yang bekerja dengan rajin dan sesuai dengan perjanjian mengenai lama kerja per hari lah yang nanti akan mendapatkan upah sebesar upa minimum yang berlaku tadi.

Rasa aman yang diciptakan oleh program ini lambat laun kan berdampak pada karakter masyarakat yang menjadi rajin dan optimal dalam bekerja. Ini merupakan pioner suksesnya program pengentasan kemiskinan tersebut. Karena dengan jaminan bahwa mereka mendapat akses ke segala macam kebutuhan pokok, maka mental miskin, suka meminta-minta, lama kelamaan akan terkikis dan digantikan dengan sikap yang lebih positif, mau bekerja keras dan ingin menhadi manusia yang lebih baik. 


\section{Fifth National Development di Thailand}

Fifth National Development Plan adalah rencana jangka menengah yang difokuskan pada program dan kebijakan pemerintah terhadap tujuan yang diinginkan yang telah ditentukan timeframe-nya. Latar belakang diluncurkannya program ini adalah untuk mengurangi angka kemiskinan di Thailand. Penekanan dari program ini dalam hal poverty reduction ialah penciptaam lapangan kerja melalui partisipasi masyarakat, seperti yang tersurat dalam temanya yaitu "broad based wealth and job creation through citizenry participation and technological advancement'. Adapun fokus dari program ini antara lain mencakup bidang keamanan, memajukan sains dan teknologi, memperluas akses masyarakat terhadap pelayanan jasa sosial, keseimbangan desa dan kota, kemudahan akses terhadap infrastruktur.

Dengan melihat tema dan fokus strategi dari program ini, maka beberapa hal yang perlu mendapat perhatian ialah penekanan terhadap metode yang digunakan yaitu mengutamakan keterlibatan masyarakat. Sehingga dampaknya yaitu masyarakat yang merasa dilibatkan dalam memajukan negaranya ini akan merasa dirinya penting dan berperan dalam proses pembangunan. Hal ini akan memberikan atmosfir positif bagi percepatan tercapainya tujuan program tersebut yaitu salah satunya adalah pengentasan kemiskinan. Selain itu, program tersebut juga menyoroti pentingnya akses masyarakat terhadap infrastruktur, sehingga distribusi menjadi lebih merata dan kebutuhan paling pokok masyarakat menjadi prioritas utama untuk dipenuhi.

\section{Perkembangan Program Penanggulangan Kemiskinan di Indonesia}

\section{Periode orde lama (tahun 1960-an)}

Program penanggulangan kemiskinan di Indonesia sudah dilaksanakan pemerintah semenjak orde lama tepatnya sejak tahun 1960-an melalui strategi pemenuhan kebutuhan pokok rakyat yang tertuang dalam Pembangunan Nasional Berencana Delapan Tahun (Penasbede). Berdasarkan TAP MPRS No. II/MPRS/1960 tentang Garis-garis Besar Pola Pembangunan Nasional Semesta Berencana Tahapan Pertama 1961-1969, pola pembangunan pada masa itu lebih ditujukan untuk mewujudkan kesejahteraan rakyat yang merata.

Pembangunan pada saat itu berorientasi pada peningkatan pendapatan nasional yang membentuk kemakmuran rakyat Indonesia (Biro Perancangan Negara, 1956). Kemakmuran di wujudkan melalui berbagai kebijakan yang akan meningkatkan pendapatan secara mandiri. Bidang pendidikan, perumahan, dan kesehatan, mendapatkan perhatian khusus dari pemerintah. Kemudian dilanjutkan kebijakan untuk peningkatan pendapatan nasional dan keluarga. Program peningkatan kualitas penduduk secara lengkap tertuang dalam dokumen Pembangunan Nasional Berencana Delapan Tahun (Penasbede, tahun 1961-1969).

Dari gambaran kebijakan pemerintah pada masa itu terlihat jelas bahwa peningkatan kualitas masyarakat dalam menanggulangi kemiskinan merupakan tujuan utama pembangunan. Namun pada pelaksanaannya, pembangunan terhenti akibat krisis politik pada masa tahun 1965. Krisis politik pada saat itu justru menambah jumlah masyarakat miskin. Hal ini disebabkan inflasi yang sangat tinggi yang mencapai $650 \%$.

Kegagalan dalam penanggulangan kemiskinan ini bukan semata-mata kesalahan dari pemerintah. Akan tetapi dikarenakan kondisi pada saat itu yang tidak menguntungkan untuk pembangunan. Kecenderungan dunia pada saat itu adalah pada politik, dan politik jarang bermakna 
membangun karena intinya adalah power strunggle. Kegagalan pembangunan pada saat itu lebih disebabkan beberapa faktor yaitu: (1) kurangnya pemahaman akan pembangunan yang memberdayakan masyarakat (pembangunan tidak berbasis rakyat), (2) rakyat dijadikan basis ideologi politik, dan (3) kurangnya kecakapan.

Selain itu program dan rencana yang disusun lebih di dominasi oleh kepentingan individu atau pribadi, dan partai lebih dominan daripada pemerintah. Sistem pemerintahan pada saat itu juga cenderung terpengaruh sistem perekonomian yang tidak sesuai dengan kondisi masyarakat yaitu liberalis (1950-1957) dan etatisme (1958-1965).

Sistem etatisme tersebut mengakibatkan: (1) rusaknya sarana produksi dan komunikasi, (2) hutang luar negeri untuk membiayai politik mercusuar, (3) defisit anggaran negara di biayai dengan mencetak uang baru sehingga inflasi sangat tinggi. Kepentingan-kepentingan politik itulah yang menyebabkan tidak terlaksanakannya program pembangunan untuk menanggulangi kemiskinan, tetapi malah sebaliknya semakin menambah jumlah masyarakat miskin.

\section{Periode orde baru}

Awal orde baru merupakan masa perbaikan seluruh sektor kehidupan kehidupan termasuk sektor ekonomi. Perbaikan itu lebih ditujukan untuk dua tujuan besar yaitu membersihkan sisasisa faham dan sistem perekonomian yang lama (liberal dan etatisme), dan menurunkan laju inflasi yang sangat tinggi. Tercatat inflasi tahun 1966 sebesar $650 \%$, tahun 1967 tercatat $120 \%$, 1968 sebesar $85 \%$, dan 1969 tercatat 9,9\%. Setelah perekonomian mulai stabil pemerintah baru mengeluarkan program-program pembangunan terutama untuk menanggulangi kemiskinan.

Mulai tahun 1970-an pemerintah memulai kembali program penanggulangan kemiskinan melalui Rencana Pembangunan Lima Tahun (Repelita)dan Pembangunan Jangka Panjang (PJP) 25 tahunan. Mulai saat itu tujuan pokok perangkat kebijakan ekonomi adalah didalam suatu sistem ekonomi campuran, yaitu untuk mencapai tingkat pertumbuhan ekonomi yang setinggitingginya. Semua perangkat kebijakan ekonomi yaitu kebijakan fiskal, kebijakan moneter, dan kebijakan luar negeri diformulasikan agar mampu mendorong tingkat pertumbuhan melalui pertambahan investasi baik di sektor swasta maupun pemerintah.

Pada era orde baru ini berdasarkan sasarannya pembangunan pemerintah dibagi menjadi dua periode:

\section{Periode tahun 1974-1988}

Rencana pembangunan lima tahun (Repelita) yang dijalankan pemerintah, khususnya Repelita I-IV di tempuh melalui program sektoral dan regional. Program sektoral merupakan program yang berorientasi pada peningkatan produksi dan pembangunan sarana dan prasarana yang menu njang pemenuhan kebutuhan dasar (basic needs approach) sepereti sandang, pangan, kesehatan. Sedangkan program regional untuk pengembangan potensi dan kemampuan sumber daya manusia khususnya daerah.

Untuk lebih mempermudah bagaiman pelaksanaan program sektoral dan regional digambarkan sebagai berikut: Pertama, program sektoral merupakan program untuk meningkatkan kesejahteraan masyarakat melalui pencapaian sasaran pembangunan darsi sektor tertentu. Pembangunan ini dilaksanakan di daerah sesuai kondisi dan potensinya. Biaya dari program ini dianggarkan dari Anggaran Pendapatan dan Belanja Negara(APBN) dan dilaksanakan oleh 
berbagai instansi dan lembaga pemerintah tingkat pusat. Pelasanaan program ini dilaksanakan oleh instansi sektor terkait dari tingkat kantor wilayah, direktorat jenderal, hingga tingkat menteri.

Sebelum program sektoral dilaksanakan dilakukan perencanaan untuk memproyeksi sasaran pembangunan sektor. Perencanaan sektoral disusun oleh Bappenas dan digunakan sebagai pedoman menyusun rencanca program lembaga. Agar masing-masing program terjadi sinkronisasi maka dilakukan koordinasi melalui Bappeda.

Program sektoral diarahkan untuk peningkatan peran serta dan pendapatana masyarakat berpenghasilan rendah dengan penyediaan kebutuhan dasar. Hal ini memberikan kesempatan kepada masyarakat miskin untuk melakukan kegiatan sosial ekonomi yang memberikan penghasilan. Kegiatan ini diprioritaskan untuk masyarakat desa yang miskin untuk meningkatakan sumber daya manusianya dan menguatkan permodalan. Program ini di dukung dengan pelatihanpelatihan mulai dari penghimpunan permodalan, penguasaan teknik produksi, pemasaran dan pengelolaan surplus. Namun hal ini hanya berlangsung sampai repelita ke IV. Untuk selanjutnya program sektoral lebih diarahkan pada industry, pariwisata, dan perhubungan.

Meskipun sudah dianggap baik dalam prakteknya program sektoral ini masih didominasi oleh instansi vertikal. Sehingga keadaan yang sebenarnya dari desa tidak dapat digambarkan. Kelemahan program ini yaitu tidak jarang pelaksanaannya tidak berbedoman pada prioritas kebutuhan desa dan efisiensi program ini. Program ini secara makro juga menimbulkan ketimpangan antar sektor, sehingga ditempuh kebijakan regional.

Kedua, program regional merupakan program yang berorientasi pada kepentingan daerah untuk menyerasikan dan mempercepat pembangunan daerah. Program ini disesuaikan dengan kebutuhan daerah dan kemampuan dari daerah tersebut. Hal ini ditujukan untuk meningkatkan kesejahteraan daerah dan menghilangkan kemikinan didaerah tersebut yang disesuaikan dengan kemampuan masyarakat setempat. Dalam program regional ini ada beberapa program yang dilaksanakan yaitu:

a. Program inpres

Program inpres memiliki beberapa tujuan antara lain: (1) pemerataan pembangunan, (2) mengurangi kesenjangan pendapatan dan mengurangi kesenjangan laju pembangunan antar daerah, (3) meningkatakan kemampuan aparat pemerintah daerah dan melaksanakan pembangunan seseai dengan kemampuan daerah dan kemampuan masyarakat setempat, tetapi tetap sejalan dengan program pembangunan nasional, (4) sebagai penjabaran dari azaz pembantuan (medebewind).

Sedangkan ciri dari program inpres adalah: (1) sumber dana berasal dari APBD dan dimasukkan sebagai penerimaan APBD, (2) program ditentukan oleh pemerintah pusat sedangkan pemerintah daerah bertugas menyusun perencanaan teknis dan melaksanakan serta mempertanggungjawabkan terhadap pemerintah pusat, (3) pembinaan, pengendalian, dan pengawasan dilakukan secara koordinatif oleh departemen teknis dan instansi terkait.

Terdapat beberapa jenis program inpres: Bantuan Pembangunan Daerah tingkat I, Bantuan Pembangunan Daerah Tingkat II, Bantuan kepala Desa/Kelurahan, Inpres Desa Tertinggal, Inpres Sarana Kesehatan, Dan Inpres Sekolah Dasar. Inpres Bantuan Pembangunan Daerah Tingkat I meliputi : (1) Bantuan Murni untuk peningkatan kemampuan aparatur pemerintah daerah tingkat I, (2) Bantuan pembangunan penghijauan dan reboisasi dan (3) Bantuan pembangunan peningkatan jalan dan jembatan propinsi. 
Sedangkan Inpres Bantuan Pembangunan Daerah Tingkat II meliputi : (1) Bantuan Murni untuk peningkatan kemampuan aparatur pemerintah daerah tingkat II, (2) Bantuan peningkatan jalan dan jembatan kabupaten/kotamadya, (3) Bantuan Rehabilitasi Lahan Kritis, (4) Bantuan Pembinaan Pendidikan Dasar, (5) Bantuan pembangunan dan pemugaran pasar, (6) Bantuan pembangunan sarana perkotaan, (7) Bantuan pembangunan perumahan, dan (8) bantuan program tata ruang, pertanahan dan lingkungan perkotaan.

Dana yang disalurkan ke daerah dijangkau dulu oleh pemerintah daerah disertai perencanaan program yang disusun oleh pemerintah daerah dengan koordinasai Bappeda Tingkat I. hal ini diharapkan program inpres ini bermanfaat sesuai dengan kemampuan dan kemauan masyarakat. Karena program yang direncanakan dalah kemauan masyarakat setempat yang telah dimusyawarahkan.

Sedangkan untuk pembangunan, Bantuan Pembangunan Desa ditujukan untuk mendorong usaha swadaya dan gotong royong masyarakat dalam membangun desa. Bantuan ini jumlahnya sama dan digunakan untuk membangun proyek yang diprioritaskan oleh masyarakat desa dan untuk menunjang kegiatan Pembina Kesejahteraan Keluarga (PKK). Perincian kegiatan yang dibiayai terdiri dari: (a) Bantuan langsung perdesa, (b) Pembinanan Kesejahteraan Keluarga, (c) Bantuan keserasian, (d) Peningkatan peranserta masyarakat dalam pembangunan, (e) Pengendalian dan pengelolaan tingkat propinsi dan kabupaten atau kota madya, (f) Bantuan hadiah juara perlombaan desa, dan (g) Bantuan pembinaan dan alokasi tingkat kecamatan.

b. Program Pengembangan Wilayah Terpadu Swadana (PPW-Swadana)

Program ini merupakan kelanjutan dari Pogram Pengembangan Wilayah. Progaram ini dilaksanakan daerah melalui dukunagn APBD, program ini untuk mensinkronkan program-program daerah dengan program sektoral. Tujuannya untuk meningkatakan tararaf hidup dan kesejahteraan masyarakat berpenghasailan rendah, baik yang berada dipedesaan maupun perkampungan kumuh diperkotaan.

PPW Swadana umumnya program berskala lebih kecildan lebih mengarah pada kebutuhan penting rakayat kecil, dengan tujuan mengembangkan sektoral berdimensi wilayah yang disesuaikan dengan kemampuan daerah tersebut.

\section{c. Program Khusus Program Pengembangan Kawasan Terpadu (PKT)}

Program ini merupakan salah stu program pembangunan yang dirancang khusus untuk menanggulangi kemiskinan dan mengembangkan kemampuan masyarakat didaerah-daerah yang relative tertinggal karena belum tersentuh program-program pembangunan dan menghadapi permasalahn khusus seperti keterpencilan lokasi, keterbatasan sumber daya alam, lahan kritis, kekurangan prasarana dan saranan fisik dan hal-hal laian yang menjadi kendala utama bagi penduduk disuatu daerah. Terpadu dimaksudkan secara serentak atau simultan melaui berbagi kegiatan sesuia permasalahan yang dihadapi oleh daerah, diharapkan untuk meningkatkan kemampuan sumberdaya manusia maupun daerah.

Kriteria yang diperlukan dalam PKT adalah: (1) kriteria uatama adalah meningkatakan partisipasi masyarakat dalam perencanaan dan pelaksanaan pembangunan, (2) memberikan hasil dalamwaktu relative pendek tetapi tetep mengarah pada kerangka pembangunan wilayah jangka panjang sesuai denagn pola dasar Pepelita masing-masing daerah. 
Perbedaan program ini dengan program pembangunan yang lain adalah usulan tentang program ini tidak terbatas pada usulan Bappeda ataupun departemen teknis saja tetapi dapat juga merupakan usulan Pemda tingkat I, Universitas, Masyarakat maupun lembaga non-pemerintah (LSM,LPSM).

Beberapa kendala yang terjadi dalam program-program pembangunan dalam upaya penanggulangan kemiskinan pada masa itu adalah sebagai berikut :

\section{a. Kendala Perencanaan}

Beberapa kendala dalam hal perencanaan antara lain (1) Kemampuan masyarakat setempat masih belum memadai untuk melakukan perencanan didaerahnya, sehingga rencana program yang dilaksanakan tidaka sesuai dengan garis besar pembangunan nasional jangka panjang. (2) anggapan bahwa mekanisme pasar selali berjalan sempurna. Hala iani menyebabkan orientasi pertumbuhan produksi yang diharapakan dapat meningkatkan kesejahteraan masyarakat secara otomatis. Padahal pada kenyataannya keadaan masyarakat dalam hal kepemilikan serta penguasaan faktor produksi tidaklah merata. Hal ini menyebabkan masyarakat yang produktivitasnya tinggi cepat berkembang dan yang lemah tidak mendapat kesempatan.

\section{b. Kendala Pelaksanaan}

Kendala dalam hal pelaksanaan antara lain : (1) kemampuan masyarakat yang terbatas baik dalam sumberdaya manusia mauapun sumberdana sehingga belumsiap mengikuti perubahan tingakat nasional. (2) dikarenakan masyarakat yang belum siap maka seringkali kegiatan diselesaiakan dengan menerima input dari luar, shingga tujuan utama uantuk memberikan kesempatan pada masyarakat setempat terabaiakan.

c. Kendala Koordinasi

Kendala dalam hal koordinasai adalah terjadi ketidaksesuaian perencanaan tingkat daerah oleh karena kondisis keadaan daerah setempat, yaitu sperti ketidaksesuaian kondisi lahan dan keadaan sosial ekonomi masyarakat yang berbeda dari pekiraan tingkat pusat.

\section{d. Kendala Monitoring dan Evaluasi}

Setelah suatu program terlaksana hal biasa terlupakan adalah monitoring dan evaluasi. Sehingga berakibat tidak terarahnya program karena terjadi penyimpangan-penyimpangan atau tiadaka langgengnya hasil-hasil positif yang ditimbulkan dari pelaksanaan suatu program. Kalaupun ada monitoring adalah pada penilaian jumlah dana yang dicairkan apakaha sesuai dengan dan yang diprogramkan. Tidak ada monitoring dan evaluasi yang memperhatikan kesesuaian hasil program dengan tujuan program. Sehingga pertimbangan antara perbandingan manfaat terabaikan.

\section{Periode 1988-1998}

Selanjutnya periode 1988-1998 yaitu pda repelita V-VI pemerintah melaksanakan program penanggulangan kemiskinan dengan strategi khusus menuntaskan masalah kesenjangan sosial-ekonomi. Jalur pembangunan ditempuh secara khusus dan mensinergikan program sektoral dan regional yang ada dalam koordinasi Inpres Nomor 3 Tahun 1993 tentang Peningkatan 
Penanggulangan Kemiskinan yang akhirnya diwujudkan melalui program IDT (Inpres Desa Tertinggal) dan beberapa program lainnya. Pada dasarnya pada periode ini program yang dilaksanakan adalah meningkatkan program-program yang telah dilaksanakan sebelumnya.

\section{1) Penajaman Program}

Selain penyempurnaan program sebelumnya, juga akan dilakukan percepatan pembangunan perdesaan yang tercermin dari sasaran meningkatkan kualitas sumber daya manusia didaerah perdesaan, terciptanya struktur perekonomian yang lebih kukuh, tersedianya prasarana dan sarana perekonomian didesa yang lebih mantap, makin berkembangnya pemahaman dan kesadaran masyarakat akan pembangunan yang berwawasan lingkungan, serta upaya pelestarian lingkungan, makin berfungsinya lembaga pemerintahan desa dan lembaga kemasyarakatan desa untuk meningkatkan pelaksanaan pembangunan perdesaan, makin terjaminnya kepastian hukum bagi masyarakat perdesaan mengenai penguasaan dan pengusahaan tanah yang sesuai hukum serta adat istiadat setempat, serta berkuranganya jumlah pendududk miskin di perdesaan dan jumlah desa tertinggal.

Dalam repelita VI untuk menyempurnakan program maka disusun Sasaran Repelita Tahunan (Sarlita). Sarliat terdiri dari Sarlita Sektoral dan Sarlita Regional. Sarlita memuat kegiatan yang dilakukan masyarakat maupun pemerintah, sasaran kegitan tahunan selama lima tahun dengan perkiraan pembiayaan dari masyarakat maupun pemerintah, dan lokasi kegiatan. Sarlita memuat lima prinsip yaitu: targeting, delivering, receiving, revolving, dan monitoring.

Prinsip targeting. Prinsip yang mensyaratkan adanya upaya perencanaan program agar dapat tepat mengenai sasaran sebagai tujuan pemerataan pembagunan. Prinsip targeting sebelumnya didahului dengan perencanaan sosial. Hal ini dikarenakan dalam menilai kemiskinan indicator yang digunakan berbeda-beda sehingga perlu diseragamkan kesamaan indikator sehingga dapat ditargetkan proses perencanaannya.

Prinsip delivering. prinsip yang mensyaratkan adanya kelancaran dan ketepatan waktu alokasi dana pembangunan. Mekanisme alokasi dana pembangunan yang lancer sangat ditentukan oleh sederhananya prosedur pencairan dana dipusat dan tertibnya administrasi proyek dari bawah.

Prinsip receiving. Prinsip yang mensyaratkan bahwa dana yang disalurkan harus tepat diterima oleh kelompok sasaran yang memerlukannya dengan memperhatikan usulan rencana dan penentuan pelaksanaan kegiatan termasuk alokasi penggunaan dana dari bawah.

Prisip revolving. Prinsip yang mensyaratkan bahwa dana yang disalurkan khususnya dana dengan maksud sebagai modal kerja dan/atau modal usaha simpan pinjam untuk meningkatkan keswadayaan dan kemandirian haraus tercipta suatau mekanisme perguliran dana yang cepat dan efektif. Masudnay dana bergulir adalah dana harus tetap berada dan digunakan untuk kegiatan sosial ekonomi masyarakat desa setempat secara berkelanjutan.

Prisip monitoring. Prinsip yang mensyaratkan bahwa program yang sedang mauapun telah dilaksanakan harus selalu dipantau dan dievaluasi. Unsur yang penting dan harus tersedia dalam proses pemantauan dan evalauasi ini adalah tersedianya data atau informasi penunjang secara lengkap tentang potensi wilayah yang melingkupi dan karakteristik penduduk miskin. Data yang sangat potensial digunakan adalah data yang dihimpun oleh Biro Pusat Statistik (BPS) dan lembaga terkait lain. Dalam pelaksanaan program harus selalu dilakukan pencatatan- 


\section{Telaah Kritis Kebijakan Penanggulan Kemiskinan dalam Tinjauan Konstitusi}

pencatatan untuk mengetahui perkembangan arah program, sebagai bahan untuk melaksanakan evaluasi.

Kemudian dengan dasar data yang diperoleh tersebut kemudian dirumuskan desain monitoring untuk menjawab tiga buah pertanyaan: (1) apakah tujuan program untuk menolong lapisan penduduk berpenghasilan rendah telah berhasil? (2) apakah tujuan program untuk meningkatkan kemampuan kelembagaan birokrasi pembangunan daerah telah dapat diwujudkan? Dan (3) apakah tujuan program untuk mendorong perkembangan wilayah telah dapat dicapai? Selanjutnya dari hasil monitoring dan evaluasi tersebut akan Nampak apakah program tersebut layak untuk tetap dilanjutkan. Selain itu hasil tersebut akan sangat berguna untuk studi perkembangan program sejenis, dan program lain yang terkait.

Semuanya itu dimaksudkan untuk meningkatkan keterpaduan antara perancanaan, pelaksanaan dan pengendalian serta evaluasi berbagai program dan proyek yang dijalankan oleh berbagai insatansi pemerintah dan lembaga non pemerintah. Keterpaduan pembangunan yang diamksud adalah proses pelaksanaan pembangunan memperhatikan keserasian, keselarasan, dan keharmonisan baik dilihat dari segi wilayah, penggunaan waktu maupun pencapaian sasaran. Keserasian berarti pelaksanaan pembagunan harus meningkatkan taraf hidup masyarakat desa. Keterpaduan berarti adanya pertalian erat antar dinas-dinas sektoral dan keterkaitan antara rencana pembangunan wilayah kecamatan, kabupaten, propinsi, dan nasional.

Dalam program repelita VI ini Bantuan Pembangunan Desa diarahkan untuk meningkatkan daya guna dalam (1) mendorong kegiatan sosial ekonomi masyarakat desa, (2) menggerakkan peran serta masyarakat, (3) memperkuat kelembagaan masyarakat, (4) meningkatkan kemampuanaparatur desa, (5) mengembangkan teknologi tepat guna perdesaan, serta (6) mengembangkan administrasi di tingkat kecamatan dan desa.

Berdasarkan arahan tesebut Bantuan Pembangunan Desa diwujudkan dalam bentuk berbagai bantuan terdiri dari bantuan untuk menunjang kegiatan PKK, pembinaan Anak dan Remaja, dan pemantaban LKMD. Pada tahun anggaran sebelumnya 1994/95 bantuan untuk pemantaban LKMD merupakan komponen bantuan yng terpisah dari bantuan langsung. Karena LKMD dirasakan komponen penting kemudian bantuan LKMD diintegrasikan dalam bantuan langsung. Bentuk-bentuk bantuan itu antara lain :

a. Bantuan Peningkatan Peran Serta Masyarakat (BP2M). Bantuan yang dimaksudkan untuk mendorong peran serta masyarakat dalam pembangunan perdesaan. Bantuan ini digunakan untuk menunjang : (1) Kegiatan Usaha Ekonomi Desa dengan praktek kerja lapangan (PKL), (2) latiahan kader pembangunan desa (KPD) dan kepala desa/lurah, dan (3) kegiatan diskusi UDKP

b. Bantuan-bantuan Berupa Pembinaan.

Bantuan Pembangunan Desa dalam mendorong usaha masyarakat desa dan memperkuat kelembagaan masyarakat.

c. Bantuan Hadiah Juara Perlombaan Desa. Bantuan ini dimaksudkan untuk sosial ekonomi produktif dan mengembangkan kelembagaan masyarakat, serta mempertahankan prestasi pembangunan yang telah dicapai, memacu pengembangan usaha.

d. Bantuan Pengendalian dan Pengelolaan. Bantuan ini dimaksudkan untuk mendukung kegiatan (1) penyuluhan dan pembinaan terhadap pelaksanaan dengan Bantuan Pembangunan Desa, (2) supervise, evaluasi, (3) penyusunan dan penyampaian pelaksanaan 
fisik dan realisasi keuangan Pembangunan Desa, (4) pertemuan/rapat teknis, (5) lembaga dana dan kredit perdesaan seperti KUD, BKD, lain (6) pengadaan dan pemeliharaan rapat kerja dan konsultasi, (7) kegiatan lainyang menunjang pendayagunaan Bantuan Pembangunan Desa, serta (8) pemantauan dan laporan perkembangan pengelolaan Bantuan pembinaan dan operasional.

\section{2) Inpres Desa Tertinggal (IDT)}

Program ini resmi dijalankan setelah adanya Instruksi Presiden Republik Indonesia Nomor 5 Tahun 1993 progaram ini ditujukan untuk menanggulangi kemiskinan dan kesenjangan ekonomi. Program ini memberikan dana kepada 20 ribu desa tertinggal dengan dana sebesar 20 juta pertahun. Program ini mengandung 3 pengertian dasar, yaitu (1) sebagai pemicu gerakan nasional penanggulangan kemiskinan, (2) sebagai strategi dalam pemerataan pembangunan, dan (3) adanya bantuan dana bergulir bagi masyarakat yang paling memerlukan. Program ini adalah program yang didalamnya terdapat semangat kebersamaan untuk maju, sebagai uapaya bersama untuk menanggulangi kemiskinan dan dapat menumbuhkan kebersamaan untuk saling memberi kesempatan berpartisipasi seluas-luasnya dalam pembangunan terutama kepada penduduk miskin. Diharapkan pula dapat terciptanya pemerataan pembangunan melalui peningkatan potensi dan kegiatan ekonomi rakyat. Program Inpres Desa Tertinggal merupakan gerakan nasional penanggulangan kemiskinan, strategi pemerataan pembangunan, dan upaya peningkatan ekonomi rakyat.

IDT merupakan perluasan dan peningkatan berbagai program dan upaya serupa yang telah dijalankan sebelumnya seperti program Pengembangan Kawasan Terpadu (PKT) dan mulai dilakasanakan pada Repelita VI. Program PKT dan program-program lain yang menangani langsung masalah kemiskinan selanjutnya diintegrasikan ke dalam program Inpres Desa Tertinggal. Program IDT ini diharapkan akan lebih mengurangi masalah kemiskinan.

Program ini mengandung tiga arahan, pertama, instruksi untuk mengkoordinasikan semua program pembangunan sektoral, regional dan khusus yang ditujukan untuk menanggulangi kemiskinan. Kedua, pemberian dana sebagai modal bagi masyarakat desa miskin untuk membangun diri sendiri melalui kegiatan sosial ekonomi untuk meningkatkan kesejahteraan secara berkelanjutan. Ketiga, koordinasi dan keterpaduan berbagai kebijakan, program, dan kegiatan, serta seluruh upaya, sumberdana dan sumberdaya yang diarahkan untuk mendukung dan memperlancar upaya peningkatan peran serta penduduk miskin dalam pembangunan.

\section{3) Pembangunan Prasarana Pendukung Desa Tertinggal (P3DT)}

Program ini merupakan pendukung sekaligus penyempurna dari program IDT. Program ini mulai dirilis pada tahun 1995, program ini menekankan pada bantuan pembangunan prasarana dan sarana dasar yang mendukung langsung kegiatan sosial ekonomi masyarakat lokal.

Program ini dilaksanakan dengan tujuan jangka panjang adalah Pemberdayaan Masyarakat melalui tujuan jangka pendek yang meliputi: (1) meningkatkan akses pemasaran dan mengurangi isolasi, (2) meningkatkan derajat kesehatan masyarakat, (3) menciptakan lapangan kerja di desa. (4) meningkatkan kemampuan kelembagaan desa/masyarakat, (5) meningkatkan ketrampilan masyarakat desa dalam perencanaan dan pelaksanaan pembangunan serta memelihara prasarana yang telah dibangun, (6) meningkatkan pembentukan modal didesa. 
Dalam mencapai keenam tujuan tersebut ditempuh dengan beberapa strategi : (1) strategi untuk mencapai tujuan pertama direncanakan pembangunan prasarana jalan, jembatan dan tambatanperahu yang akan membuka isolasi daerah dan memudahkan masyarakat desa memasarkan hasil produksi, sehingga harga jual yang diperoleh lebih tinggi dan memudahkan memperoleh kebutuhan sehari-hari yang dating dari luar dengan harga beli yang lebih rendah, (2) strategi untuk mencapai tujuan kedua, dengan dibangunnya prasarana air bersih dan penyehatan lingkungan untuk meningkatkan kesehatan masyarakat, (3) strategi untuk mencapai tujuan ketiga, dicapai dengan melaksanakan proyek tersebut dengan sistem padat karya dengan tetap memperhatikan kaidah teknis dan penggunaan bahan local yang tersedia di desa, (4) strategi untuk mencapai tujuan keempat, dengan melakukan mekanisme perencanaan dari bawah (bottom up) untuk menentukan prasarana yang akan dibangun, (5) strategi untuk mencapai tujuan kelima yaitu meningkatkan ketrampilan masyarakat desa yang ditempuh dengn pelaksanaan pekerjaan konstruksi dilaksanakan langsung oleh masyarakat, (6) strategi untuk mencapai tujuan keenam, yaitu meningktakan pembentukan modal didesa adalah dengan memanfaatkan tenaga dan bahan lokal sebanyak mungkin, sehingga dana yang ada dapat berputar didesa.

Sedangkan jenis prasarana yang dibangun sesuai dengan tujuan P3DT terdiri dari: (1) jalan dan jembatan, (2) tambatan perahu, (3) prasarana air bersih, (4) sanitasi/MCK (Mandi Cuci Kakus). Seperti yang di ketahui bahwa pelaksanaan IDT maupun P3DT adalah memberdayakan potensi desa tersebut agar desa dapat berkembang dan mendapatkan manfaat, sekaligus yang paling utama adalah menanggulangi kemiskinan yang ada.

Program-progaram penanggulangan kemiskinan tersebut semuanya seakan-akan tidak berhasil setelah Indonesia dilanda krisis tahun 1997/1998. Kemiskinan yang semula diharapkan mampu diturunkan dengan program-program pemerintah tersebut justru mengalami peningkatan yang sangat drastis.

Beberapa koreksi terhadap penanggulangan kemiskinan selama ini adalah pendekatan penanggulangan kemiskinan perlu mempertimbangkan beberapa aspek strategis (Mubyarto, 2002) sebagai berikut : (1) indikator keberhasilan individu perlu dikomplemen dengan prestasi kelompok masyarakat, (2) paradigma penanggulangan kemiskinan dengan pengakuan terhadap potensi partisipatif dan modal sosial kaum miskin untuk mengembangkan diri, (3) kewenangan menentukan sendiri aktivitas penanggulangan kemiskinan, dan meniadakan ego-sektoral yang bersifat tumpang tindih, tidak efektif, dan kurang efisien, (4) menumbuhkan sendiri prinsip transparansi dan akuntabilitas di tingkat masyarakat desa, (5) melakukan reposisi peran pihakpihak luar desa dari agen pembangunan menjadi fasilitator pemberdayaan, dan (6) percepatan transformasi struktural ekonomi perdesaan melalui pengembangan strategi pertumbuhan inklusif sektor pertanian dan perdesaan.

\section{Periode 1998-2007}

Program yang dilaksanakam pada masa ini adalah program-program penanggulangan kemiskinan pada saat krisis dan pasca krisis ekonomi tahun 1997/1998. Krisis ekonomi mengakibatkan bertambahnya jumlah penduduk miskin. Menurut perhitungan BPS, jumlah penduduk miskin meningkat menjadi 49,5 juta jiwa (24,2\%) pada tahun 1998. Pemerintah telah berhasil memperbaiki kondisi perekonomian melalui pengendalian harga barang dan jasa, serta 
meningkatkan pendapatan masyarakat, sehingga jumlah penduduk miskin menurun secara bertahap dari semula 49,5 juta jiwa (24,2\%) pada tahun 1998 menjadi 36,1 juta jiwa $(16,6 \%)$ pada 2004. Dari jumlah penduduk miskin tersebut, 11,5 juta jiwa $(12,6 \%)$ berada di perkotaan dan 24,6 juta jiwa $(19,5 \%)$ berada di perdesaan. Penurunan ini merupakan dampak dari hasil transfer pendapatan berbagai program pembangunan termasuk jaring pengaman sosial yang dirancang khusus untuk mengatasi dampak negatif krisis (SNPK, 2005).

\section{1) Jaring Pengaman Sosial (JPS)}

Untuk mengatasi kemiskinan yang lebih buruk pemerintah selanjutnya mengeluarkan program Jaring Pengaman Sosial (JPS) yang di koordinasikan melalui Keppres Nomor 190 tahun 1998 tentang Pembentukan Gugus Tugas Peningkatan Jaring Pengaman Sosial. Program ini merupakan upaya pemerintah untuk menyalurkan bantuan kepada masyarakat dalam wadah pengelolaan keuangan yang lebih terpadu, transparan, dapat dipertanggungjawabkan, dan memberikan akses langsung kepada masyarakat secara cepat serta berkesinambungan.

Program ini tercipta karena adanya kesadaran akan krisis yang beralih dengan cepat sekali dari suatu krisis moneter menjadi krisis ekonomi, krisis keamanan dan akhirnya jadi suatu krisis politik sosial dan krisis moral.

Tujuan pokok dari program ini adalah : (1) menciptakan kesempatan kerja produktif bagi para penganggur diberbagai sektor kegiatan ekonomi, (2) meningkatkan pendapatan dan daya beli masyarakat, (3) meningkatkan kesejahteraan sosial-ekonomi masyarakat, terutama yang terkena dampak langsung kondisi krisis, dan, (4) mengkoordinasikan berbagi program pembangunan penanggulangan dampak krisis dan berbagai program penanggulangan kemiskinan.

Program ini meliputi empat prioritas: (1) program ketahanan pangan, dilaksanakan agar masyarakat miskin dapat memperoleh pangan dengan mudah dan terjangkau, program ini dilaksanakan melalui empat skim yaitu skim cadangan pangan, skim bantuan pangan, skim intensifikasi produksi pangan, skim subsidi pupuk dan modal, (2) program padat karya dan penciptaan lapangan kerja produktif, (3) program pengembangan usaha kecil dan menengah, (4) program peningkatan pelayanan sosial.

Program ini mengalami dua kendala utama: (1) data yang akurat dan lengkap mengenai pendududk miskin di suatu daerah terbatas, (2) sistem pemantauan dan pengendalian pelaksanaan JPS dilapangan masih belum memadai. Sehingga pada saat itu pemerintah mengeluarkan Keppres No. 190/1998 mengenai pembentukan gugus tugas peningkatan JPS. Hal ini dilakukan untuk mencegah terjadinya kebocoran dana.

Selanjutnya pemerintah melalui Keputusan Presiden Nomor 124 Tahun 2001 membentuk Komite Penanggulangan Kemiskinan (KPK) yang berfungsi sebagai forum lintas pelaku dalam melakukan koordinasi perencanaan, pembinaan, pemantauan dan pelaporan seluruh upaya penanggulangan kemiskinan. Untuk lebih mempertajam keberadaan Komite Penanggulangan Kemiskinan maka pada tanggal 10 September 2005 dikeluarkan Peraturan Presiden Nomor 54 Tahun 2005 tentang Tim Koordinasi Penanggulangan Kemiskinan (TKPK). Keberadaan TKPK diharapkan melanjutkan dan memantapkan hasil-hasil yang telah dicapai oleh KPK. Sesuai dengan Peraturan Presiden Nomor 54 Tahun 2005 tugas dari TKPK adalah melakukan langkah-langkah konkret untuk mempercepat pengurangan jumlah penduduk miskin di seluruh wilayah NKRI melalui koordinasi dan sinkronisasi penyusunan dan pelaksanaan penajaman kebijakan penanggulangan kemiskinan. 


\section{2) Program Pengembangan Kecamatan (PPK)}

Program ini merupakan upaya pemerintah dalam uapay menanggulangi kemiskinan pada saat krisis sekaligus merupakan kelanjutan dan pengembangan dari IDT dan P3DT. PPK adalah salah satu upaya Pemerintah Indonesia untuk meningkatkan kesejahteraan masyarakat perdesaan, memperkuat institusi lokal, dan meningkatkan kinerja pemerintah daerah. Program ini mengusung sistem pembangunan bottom up planning, program pembangunan yang direncanakan dan dilaksanakan oleh masyarakat. PPK berada dibawah binaan Direktorat Jenderal Pemberdayaan Masyarakat dan Desa (Ditjen PMD), Departemen Dalam Negeri (Depdagri). Pembiayaan program berasal dari alokasi APBN, APBD, dana hibah lembaga/ negara pemberi bantuan, serta kontribusi Grup Bank Dunia.

PPK merupakan program pemberdayaan masyarakat terbesar di Indonesia ini. Terbesar karena cakupan wilayah, serapan dana, kegiatan yang dihasilkan dan jumlah pemanfaatnya. PPK menyediakan dana bantuan secara langsung bagi masyarakat (BLM). Besarnya BLM antara Rp500 juta - Rp1 miliar per kecamatan, tergantung dari jumlah penduduk. Program yang mengusung sistem pembangunan bottom up planning yang diusulkan langsung dan dilaksanakan oleh masyarakat. Masyarakat desa bersama-sama terlibat dalam proses perencanaan partisipatif dan pengambilan keputusan penggunaan dana BLM. Penggunaan BLM dilakukan atas dasar kebutuhan pembangunan dan prioritas yang ditentukan bersama dalam forum musyawarah.

PPK cepat tanggap merespons dan membantu lokasi/ korban bencana alam. Untuk wilayah paska-bencana seperti Provinsi Nanggroe Aceh Darussalam (NAD); Kepulauan Nias, Sumatera Utara; DIY dan Klaten, Jawa Tengah; PPK melaksanakan program khusus rehabilitasi dengan alokasi dana yang lebih tinggi. Program PPK ini dianggap pemerintah sebagai program yang berhasil sehingga program PPK dan P2KP dijadikan dasar terbentuknya program selanjutnya yaitu PNPM-Mandiri.

\section{3) Program Penganggulangan Kemiskinan Perkotaan (P2KP)}

Program ini merupakan program yang mengikutkan masyarakat dalam memikirkan permasalahan kemiskinan, merencanakan, dan melaksanakan sekaligus mengawasi berbagi persoalan yang dihadapi oleh lingkungan mereka sendiri. Program P2KP dan PPK merupakan program yang melompati birokrasi. Program ini merupakn kerjasama antara pemerintah Indonesia dengan Bank Dunia melalui Loan IDA credit yang merupakan program penanggulangan kemiskinan berbasis pemberdayaan masyarakat.

Selain PPK dan P2KP pada era ini juga ada program Bantuan Langsung Tunai (BLT) hal ini di maksudkan untuk pengganti subsidi BBM yang dicabut. Pemerintah mengganti dan mengembangkan kebijakan penanggulangan kemiskinan sesuai dengan era masa jabatan presiden. Secara ringkas jika disebutkan macam kebijakan yang diambil sesuai era presiden menjabat adalah sebagai berikut (Litbang KOMPAS dalam Prihatini):

1. Era Presiden Soekarno : - Pembangunan Nasional Berencana 8 tahun (Penasbede)

2. Era Presiden Soeharto : - Repelita I - IV melalui program Sektoral \& Regional

- Repelita IV - V melalui program Inpres Desa Tertinggal

- Program Pembangunan Keluarga Sejahtera

- Program Kesejahteraan Sosial

- Tabungan Keluarga Sejahtera

- Kredit Usaha Keluarga Sejahtera 
- GN-OTA

- Kredit Usaha Tani

3. Era Presiden Habiebie :

- Jaring Pengaman Sosial

- Program Penanggulangan Kemiskinan \& Perkotaan

- Program Pembangunan Prasarana Pendukung Desa Tertinggal

- Program Pengembangan Kecamatan

4. Era Presiden Gusdur :

- Jaring Pengaman Sosial

- Kredit Ketahanan Pangan

- Program Penangggulangan Kemiskinan \& Perkotaan

5. Era Presiden Megawati:

- Pembentukan Komite Penganggulangan Kemiskinan

- Program Penanggulangan Kemiskinan di Perkotaan

6. Era Presiden SBY :

- Pembentukan Tim Koordinasi Penanggulangan Kemiskinan

- Bantuan Langsung Tunai

- Program Pengembangan Kecamatan

- Program Penanggulangan Kemiskinan di Perkotaan

- Program Nasional Pemberdayaan Masyarakat

Selain program-program diatas telah dibuat juga Strategi Nasional Penanggulangan Kemiskinan (SNPK) yang kemudian dintegrasi menjadi Dokumen Rencana Pembangunan Jangka Menengah (RPJM) tahun 2004-2009 yang kemudian dilanjutkan dengan Rencana Pembangunan Jangka Menengah Nasional (RPJMN) tahun 2010-2014 sesuai Peraturan Presiden Republik Indonesia Nomor 5 Tahun 2010.

\section{Penanggulangan Kemiskinan dalam Tinjauan Konstitusi}

Negara yang dalam hal ini diwakili oleh pemerintah sudah sejak lama diamanati UUD 1945 untuk menganggulangi berbagai permasalahan kemiskinan. Seperti yang telah termaktub dalam batang tubuh UUD 1945 diantaranya sebagai berikut:

(1) Pasal 18 B ayat 1:"Negara mengakui dan menghormati kesatuan-kesatuan masyarakat hukum adat beserta hak-hak tradisionalnya sepanjang masih hidup dan sesuai dengan perkembangan masyarakat dan prinsip Negara Kesatuan Republik Indonesia, yang diatur dalam undang-undang"

Pasal 18 B ayat 1 menjelaskan bahwa selain memberlakukan hukum negara, negara tetap mengakui dan menghormati hukum adat dan hak-hak tradisionalnya, selama hukum adat dan hak tradisional itu masih ada dan selama sesuai dengan perkembangan masyarakat serta tetap menjunjung tinggi prinsip Negara Kesatuan Republik Indonesia ketentuan mengeai hukum adat ini diatur dalam undang-undang.

(2) Pasal 27 ayat 2 : "Tiap-tiap warga negara berhak atas pekerjaan dan penghidupan yang layak bagi kemanusiaan". 
Pasal 27 ayat 2 menjelaskan bahwa setiap warga Negara Indonesia berhak mendapatkan pekerjaan dan penghidupan yang layak bagi kemanusiaan. Tentunya ini memberikan tanggung jawab kepada pemerintah untuk mengadakan lapangan kerja supaya setiap warga Negara Indonesia mendapatkan pekerjaan. Namun tanggung jawab pemerintah tidak hanya sampai masyarakat mendapatkan pekerjaan, tetapi juga penghidupan yang layak yang berarti mampu mencukupi kebutuhan, terutama kebutuhan pokok.

(3) Pasal 28 A: "Setiap orang berhak untuk hidup serta berhak mempertahankan hidup dan kehidupannya."

Pasal 28 A dan pasal 28 B ayat 2 ini menjelaskan bahwa tiap orang mempunyai hak untuk hidup dan bertahan hidup serta perlindungan terhadap setiap anak. Pasal ini juga termasuk dasar perlindungan terhadap setiap warga Negara dari setiap hal yang membahayakan kehidupannya. Serta perlindungan dari tindak kekerasan dan diskriminasi.

(4) Pasal 28 B ayat 2 : "Setiap anak berhak atas kelangsungan hidup, tumbuh, dan berkembang serta berhak atas perlindungan dari kekerasan dan diskriminasi."

(5) Pasal $28 \mathrm{C}$ :

a. Ayat 1: "Setiap orang berhak mengembangkan diri melalui pemenuhan kebutuhan dasarnya, berhak mendapat pendidikan dan memperoleh manfaat dari ilmu pengetahuan dan teknologi, seni dan budaya, demi meningkatkan kualitas hidupnya dan demi kesejahteraan umat manusia."

b. Ayat 2: "Setiap orang berhak untuk memajukan dirinya dalam memperjuangkan haknya secara kolektif untuk membangun masyarakat, bangsa dan negaranya."

Pasal $28 \mathrm{C}$ menjelaskan bahwa setiap orang berhak berusaha untuk mengembangkan diri atau berusaha untuk memenuhi kebutuhan dasarnya. Berhak mendapatkan pendidikan serta sgala hal yang berhubungan IPTEK, seni dan budaya, tidak ada pembatasan dan perbedaan kepada warga Negara di Indonesia.

(6) Pasal 28 D :

a. Ayat 1: "Setiap orang berhak atas pengakuan, jaminan, perlindungan, dan kepastian hukum yang adil serta perlakuan yang sama dihadapan hukum.

b. Ayat 2: "Setiap orang berhak untuk bekerja serta mendapat imbalan dan perlakuan yang adil dan layak dalam hubungan kerja."

c. Ayat 3: "Setiap warga negara berhak memperoleh kesempatan yang sama dalam pemerintahan."

d. Ayat 4: "Setiap orang berhak atas status kewarganegaraan".

Pasal 28 D ayat 1 menjelaskan bahwa setiap orang berhak mendapatkan perlakuan yang sama dihadapan hukum dan memperolah pengakuan, jaminan, perlindungan, dan kepastian hukum yang sama tanpa ada pembedaan. Pasal 28 D ayat 2 menjelaskan bahwa setiap orang berhak untuk bekerja/ memperoleh pekerjaan dan berhak mendapatkan imbalan yang adil sesuai dengan standartnya serta mendapatkan perlakuan yang adil juga dalam hubungn kerja. Pasal $28 \mathrm{D}$ ayat 3 dan 4 menjelaskan tentang kesamaan dalam kesempatan dalam pemerintahan/hak untuk berpolitik dan hak kewarganegaraan.

(7) Pasal 28 F : "Setiap orang berhak untuk berkomunikasi dan memperoleh informasi untuk mengembangkan pribadi dan lingkungan sosialnya, serta berhak untuk mencari, memperoleh, 


\section{Journal of Indonesian Applied Economics}

Vol. 5 No. 1 Mei 2011, 1-27

memiliki, menyimpan, mengolah, dan menyampaikan informasi dengan menggunakan segala jenis saluran yang tersedia."

Pasal $28 \mathrm{~F}$ menjelaskan tentang komunikasi dan informasi, yang tentunya ini akan menimbulkan kewajiban bagi pemerintah untuk melakukan perlindungan kepada masyarakat terhadap masalah komunikasi dan informasi, termasuk melindungi masyarakat dari kejahatan yang berhubungan dengan komunikasi dan informasi.

(8) Pasal 28 G ayat 1: "Setiap orang berhak atas perlindungan diri pribadi, keluarga, kehormatan, martabat, dan harta benda yang di bawah kekuasaannya, serta berhak atas rasa aman dan perlindungan dari ancaman ketakutan untuk berbuat atau tidak berbuat sesuatu yang merupakan hak asasi."

Pasal $28 \mathrm{G}$ ayat 1 menjelaskan tentang hak pribadi masyarakat hak untuk memperoleh perlindungan keluarga, kehormatan, martabat dan harta benda serta hak memperoleh rasa aman dari ancaman ketakutan.

(9) Pasal $28 \mathrm{H}$ :

a. Ayat 1: "Setiap orang berhak hidup sejahtera lahir dan batin, bertempat tinggal, dan mendapatkan lingkungan hidup baik dan sehat serta berhak memperoleh pelayanan kesehatan".

b. Ayat 2 : "Setiap orang berhak mendapat kemudahan dan perlakuan khusus untuk memperoleh kesempatan dan manfaat yang sama guna mencapai persamaan dan keadilan".

c. Ayat 3 : "Setiap orang berhak atas jaminan sosial yang memungkinkan pengembangan dirinya secara utuh sebagai manusia yang bermartabat".

d. Ayat 4 : "Setiap orang berhak mempunyai hak milik pribadi dan hak milik tersebut tidak boleh diambil alih secara sewenang-wenang oleh siapa pun.

Pasal $28 \mathrm{H}$ ayat 1 menjelaskan tentang hak untuk hidup sejahtera lahir dan batin, bertempat tinggal, dan mendapat lingkungan yang baik, serta hak masyarakat untuk memperoleh pelayanan kesehatan.

Pasal $28 \mathrm{H}$ ayat 2 menjelaskan tentang hak memperoleh kesempatan dan manfaat. Pasal $28 \mathrm{H}$ ayat 3 menjelaskan tentang memperoleh jaminan sosial. Pasal $28 \mathrm{H}$ ayat 4 menjelaskan tentang hak milik pribadi.

(10) Pasal 28 I :

a. Ayat 1: "Hak untuk hidup, hak untuk tidak disiksa, hak untuk kemerdekaan pikiran dan hati nurani, hak beragama, hak untuk tidak diperbudak, hak untuk diakui sebagai pribadi dihadapan hukum, dan hak untuk tidak dituntut atas dasar hukum yang berlaku surut adalah hak asasi manusia yang tidak dapat dikurangi dalam keadaan apapun."

b. Ayat 2: "Setiap orang bebas dari perlakuan yang bersifat diskriminatif atas dasar apapun dan berhak mendapatkan perlindungan terhadap perlakuan yang bersifat diskriminatif itu."

c. Ayat 4: "Perlindungan, pemajuan, penegakan, dan pemenuhan hak asasi manusia adalah tanggung jawab negara, terutama pemerintah."

d. Ayat 5: "Untuk menegakkan dan melindungi hak asasi manusia sesuai dengan prinsip negara hukum yang demokratis, maka pelaksanaan hak asasi manusia dijamin, diatur, dan dituangkan dalam peraturan perundang-undangan." 
Pasal 28 I ayat 1 mejelaskan tentang warga memiliki hak untuk hidup, hak untuk tidak disiksa, hak untuk kemerdekaan pikiran dan hati nurani, hak beragama, hak untuk tidak diperbudak, hak untuk diakui sebagai pribadi dihadapan hukum, dan hak untuk tidak dituntut atas dasar hukum yang berlaku surut adalah hak asasi manusia. Pasal 28 I ayat 2 tentang hak memperoleh perlindungan dari perlakuan diskriminatif. Pasal 28 ayat 3 tentang kewajiban Negara terhadap HAM. Pasal 28 I ayat 4 menjelaskan tentang jaminan HAM. Pasal 28 I ayat 5 menjelaskan tentang perlindungan hukum terhadap HAM.

(11) Pasal 31 ayat 1: "Tiap-tiap warga negara berhak mendapat pendidikan"

Pasal 31 ayat 1 menjelaskan tentang hak warga untuk memperoleh pendidikan. Tentunya menjadi dasar kewajiban pemerintah menyediakan fasilitas pendidikan oleh pemerintah.

(12) Pasal 33 :

a. Ayat 1 : "Perekonomian disusun sebagai usaha bersama berdasar atas asas kekeluargaan".

b. Ayat 2 : "Cabang-cabang produksi yang penting bagi negara dan yang menguasai hajat hidup orang banyak dikuasai oleh negara".

c. Ayat 3 : "Bumi dan air dan kekayaan alam yang terkandung didalamnya dikuasai oleh negara dan dipergunakan untuk untuk sebesar-besar kemakmuran rakyat".

d. Ayat 4 : "Perekonomian nasional diselenggarakan berdasar atas demokrasi ekonomi dengan prinsip kebersamaan, efisiensi berkeadilan, berkelanjutan, berwawasan lingkungan, kemandirian, serta dengan menjaga keseimbangan kemajuan dan kesatuan ekonomi nasional".

Pasal 33 ayat 1, 2, 3 menjelaskan tentang dasar perekonomian Indonesia sekaligus sebagai dasar terbentuknya Koperasi, BUMN, dan BUMS. Pasal 33 ayat 4 menjelaskan pelaksanaan perekonomian nasional yang dilaksanakan di Indonesia.

(13) Pasal 34 :

a. Ayat 1 : "Fakir miskin dan anak-anak terlantar dipelihara oleh negara".

b. Ayat 2 : "Negara mengembangkan sistem jaminan sosial bagi seluruh rakyat dan memberdayakan masyarakat yang lemah dan tidak mampu sesuai dengan martabat kemanusiaan".

c. Ayat 3 : "Negara bertanggung jawab atas penyediaan fasilitas pelayanan kesehatan dan pelayanan umum".

Pasal 34 ayat 1 menjelaskan tanggung jawab pemerintah dalam memelihara fakir miskin dan anak terlantar. Pasal 34 ayat 2 menjelaskan tentang jaminan sosial kepada masyarakat. Pasal 34 ayat 3 menjelaskan bahwa pemerintah wajib menyediakan fasilitas pelayanan kesehatan dan pelayanan umum.

Berdasarkan penjelasan pasal-pasal tersebut di atas telah jelas tentang hak dari setiap warga negara. Sehingga untuk menangani kemiskinan pemerintah harus berusaha agar hak-hak tersebut terpenuhi dengan demikian kemiskinan dapat ditanggulangi. Karena menurut definisi kemiskinan adalah tidak terpenuhinya hak-hak dasar dari warga Negara Indonesia. Sedangkan hak-hak dasar warga Negara Indonesia adalah seperti yang tersebut dalam UUD 1945. 


\section{Formulasi Strategi Penanggulangan Kemiskinan: Tinjauan Konstitusi}

Berdasarkan UUD 1945 strategi penanggulangan kemiskinan yang dapat diterapkan adalah sebagai berikut :

1. Perlindungan pekerja oleh pemerintah, hal ini sesuai dengan Pasal 27 ayat 2 dan Pasal 28 D Ayat 2. Dalam hal ini pemerintah sesuai dengan UUD 1945 harus memberikan perlindungan terhadap pekerja agar para pemilik perusahaan memberikan imbalan yang sesuai dengan pekerjaan yang dilakukan oleh pekerja. Sehingga masyarakat dapat memenuhi kebutuhan hidupnya. Hal yang pertama yang harus dilakukan pemerintah adalah penghapusan sistem kontrak karena sisitem ini sama sekali tidak berpihak kepada pekerja, serta tidak sesuai dengan UUD 1945.

2. Program untuk pendidikan gratis, hal ini sesuai dengn Pasal 28 C Ayat 1 dan Pasal 31 ayat 1. Pemerintah harus memberikan pendididkan yang benar-benara gratis kepada masyarakat karena ini memang hak warga Negara seperti yang tertulis dalam pasal-pasal tersebut. Selain itu pendidikan merupakan investasi jangka panjang, dengan masyarakat yang cerdas tentunya akan memungkinkan penciptaan lapangan kerja yang baru dimasa depan sehingga dapat mengurangi pengangguran. Selain itu prerlu juga dibenahi pola pendidikan supaya menciptakan lulusan yang mandiri yang tidak tergantung pada lowongan pekerjaan.

3. Layanan kesehatan gratis, pemerintah harus menyediakan pelayaan kesehatan gratis terutama untuk penduduk miskin sesuai dengan Pasal $28 \mathrm{H}$ ayat 1 dan Pasal 34 Ayat 3. Kesehatan sama pentingnya dengan pendidikan karena Negara membutuhkan SDM yang cerdas dan sehat. Dengan layanan kesehatan gratis tentunya akan menguragi jumlah angka kematian dan kesehatan masyarakat akan meningkat sehingga program-program pembangunan dan penanggulangan kemiskinan dapat terlaksana.

4. Program yang ditujukan untuk penciptaan lapangan kerja, pemerintah harus mendorong penciptaan lapangan kerja sesuai dengan pasal 33 ayat 1 sebenarnya program yang sesuai adalah koperasi. Namun saat ini koperasi hanya menjadi sebuah nama yang didalamnya bukan koperasi. Koperasi sekarang bukan usaha bersama tapi berubah menjadi usaha perorangan untuk mencari keuntungan. Pemerintah harus mendorong setiap usaha diberbagai sektor, terutama sektor pertanian harus mendapat perhatian karena banyak lahan yang telah habis karena pembangunan. Selain itu perlu adanya pengembangan teknologi untuk menciptakan pertanian yang lebih modern.

5. Jaminan sosial untuk masyarakat miskin, jaminan sosial ini sesuai dengan Pasal 34 Ayat 2. Masyarakat miskin wajib mendapatkan jaminan sosial agar lebih semangat dalam hidup sehingga dapat memberikan kontribusinya kepada Negara. Dengan jaminan sosial tersebut masyarakat akan lebih merasa terjamin dan aman.

6. Perlindungan terhadap hak orang miskin, hal ini dikarenakan kemiskinan membatasi hak rakyat untuk (1) memperoleh pekerjaan yang layak bagi kemanusiaan; (2) Hak rakyat untuk memperoleh perlindungan hukum; (3) Hak rakyat untuk memperoleh rasa aman; (4) Hak rakyat untuk memperoleh akses atas kebutuhan hidup (sandang, pangan, dan papan) yang terjangkau; (5) Hak rakyat untuk memperoleh akses atas kebutuhan pendidikan; (6) Hak rakyat untuk memperoleh akses atas kebutuhan kesehatan; (7) Hak rakyat untuk memperoleh keadilan; (8) Hak rakyat untuk berpartisipasi dalam pengambilan keputusan publik dan pemerintahan; (9) Hak rakyat untuk berinovasi; (10) Hak rakyat menjalankan hubungan 
spiritualnya dengan Tuhan; dan (11) Hak rakyat untuk berpartisipasi dalam menata dan mengelola pemerintahan dengan baik. Perlindungan terhadap hak orang miskin ini sesuai dengan pasal-pasal yang terdapat dalam UUD 1945. Hak-hak orang miskin ini perlu dilindungi karena akan memperparah kondisi masyarakat miskin.

Pelaksanaan strategi penanggulangan kemiskinan itu harus diterapkan dalam kebijakan nasional maupun daerah yang saling mendukung dan berkelanjutan. Karena untuk menanggulangi kemiskinan memerlukan waktu tidak dapat dilakukan dalam waktu yang pendek. Program pembangunan yang baik yang pernah dilaksanakan di Indonesia yaitu pada masa orde baru namun pelaksanaannya yang banyak kendala dan kesalahan terutama dikarenakan masalah birokrasi dan KKN yang menyebabkan banyak terjadi penyimpangan. Selain itu dikarenakan dana pembangunan terlalu bergantung pada dana hutang luar negeri yang menyebabkan perekonomian keropos yang akhirnya hancur terkena krisis.

\section{E. KESIMPULAN DAN REKOMENDASI}

\section{Kesimpulan}

Kesimpulan yang didapatkan dari uraian sebelumnya adalah sebagai berikut.

1. Program penanggulangan kemiskinan merupakan agenda yang utama dari pemerintah namun banyak kendala dalam pelaksanaannya. Kendala yang menyebabkan kegagalan mulai dari politik, birokrasi, pelaksanaan program yang tumpang tindih, KKN, dll.

2. Pelaksanaan program penanggulangan kemiskinan yang mengagumkan pernah terjadi di Indonesia pada era orde baru, dimana masyarakat masyarakat miskin yang semula $40 \%$ menjadi 11,3\%. Namun program tersebut pun akhirnya gagal disebabkan krisis ekonomi, yang mana menghancurkan semua program penanggulangan kemiskinan.

3. Kemiskinan tidak mungkin dapat ditanggulangi hanya dalam satu periode pemerintahan, namun harus menjadi agenda jangka panjang yang terus-menerus dilaksanakan. Kemiskinan tidak mungkin dapat diselesaikan apabila tiap periode pemerintahan berganti-ganti program yang dilaksanakan.

4. Strategi penanggulangan kemiskinan harus sesui dengn UUD 1945 diantaranya program pendidikan gratis, layanan kesehatan gratis, jaminan pekerjaan, jaminan sosial, dan perlindungan semua hak-hak semua warga Negara disini di utamakan masyarakat miskin karena masyarakat miskin yang seringkali tidak mendapatkan haknya.

\section{Rekomendasi}

1. Program penanggulangan kemiskinan harus seseui dengan amanat konstitusi dan selalu berkelanjutan. Program pembangunan pemerintah pada era sekarang tertuang dalam peraturan presiden No.5 Tahun 2010 tentang Rencana Pembangunan Jangka Menegah Nasional Tahun 2010-2014, program pembangunan ini harus tetap memprioritaskan penanggulangan kemiskinan dan pelaksanaannya harus selalu diawasi dan dievaluasi. Jangan sampai program pembangunan selalu berganti-ganti tiapa periode pemerintahan sehingga sasarnny yang dituju menjadi tidak jelas.

2. Pemerintah harus mengusahakan pendidikan gratis, layanan kesehatan gratis, jaminan pekerjaan, jaminan sosial dan perlindungan hak-hak masyarakat miskin, karena semua itu 
adalah hak warga Negara seperti yang tertuang dalam UUD 1945. Sehingga merupakan kewajiban pemerintah untuk memenuhinya.

3. Program penaggulangan kemiskinan harus difokuskan pada penciptaan masyarakat yang mandiri yang mampu menciptakan lapangan kerja bukan bantuan seperti BLT yang mungkin hanya dinikmati sekejap saja.

\section{DAFTAR PUSTAKA}

Arsyad, Lincolin. 1992. Ekonomi Pembangunan. STIE YKPN. Yogyakarta.

Asra, Abuzar. 1989. Poverty Trend In Indonesia 1970-1987. Jurnal Ekonomi dan Keuangan Indonesia, Vol. 37 No. 3. Jakarta

Basri, Faisal. 1995. Profil dan Penanggulangan Kemiskinan di Indonesia. Erlangga. Jakarta.

Bhagwati, Jagdish. 1966. The Economic of Under Development Countries. McGraw-Hill Book Company. New York, Toronto.

Bigsten, Arne. 1994. Kemiskinan, Ketimpangan, dan Pembangunan, dalam Norman Gemmel (ed). Ilmu Ekonomi Pembangunan, beberapa survey. LP3ES. Jakarta.

Chambers, Robert. 1995. "Poverty and Livelihoods: Whose Reality Count ?" dalam Uner Kirdar dan Leonard Silk ( ed ). People from Impoverishment to Empowerment. New Yok University. New York

Direktorat Jenderal Perumahan dan Permukiman Departemen Permukiman dan Prasarana Wilayah. 2002. Pedoman Umum Proyek Penanggulangan Kemiskinan di Perkotaan. Penerbit Proyek Pengembangan Kecamatan Perkotaan. Jakarta.

Direktorat Jenderal Perumahan dan Permukiman Departemen Permukiman dan Prasarana Wilayah. 2002. Pegangan Pelaku Kader Masyarakat Proyek Penanggulangan Kemiskinan di Perkotaan. Penerbit Proyek Pengembangan Kecamatan Perkotaan. Jakarta.

Indriantoro, Nur dan Bambang Supomo. 2002. Metodologi Penelitian Bisnis. Penerbit BPFE. Yogyakarta.

Krause, Walter. 1962. Economic Development, The Underdevelopment World and The American Interest. Wadsworth Publishing Company. Belmont, California.

Meier, Gerald M. dan Robert Baldwin. 1965. Pembangunan Ekonomi, terjemahan, Sihotang. Bhratara. Jakarta.

Mubyarto. 1995. Ekonomi dan Keadilan Sosial. Aditya Media. Jakarta.

Mubyarto, 2002. Penanggulangan Kemiskinan di Jawa Tengah. Jurnal Ekonomi Rayat. Artikel Tahun I No. 7, November 2002, Jakarta. www.ekonomi rakyat.org.

Nasir, Moh. 1988. Metode Penelitian. Ghalia Indonesia. Jakarta.

Nasution, Anwar. 2002. The Indonesian Economic Recovery From The Crisis in 1997-1998. Journal of Asia Economics 165. North-Holland.

Ngatimin. 2001. Penanggulangan Kemiskinan Perkotaan (Thesis). Program Pasca Sarjana Universitas Brawijaya. Malang 
Octaviani, Dian. 2001. Inflasi, Pengangguran, dan Kemiskinan di Indonesia: Analisis Indeks Forrester Greer \& Horbecke. Media Ekonomi, Vol. 7 No. 2 Agustus 2001. Jakarta.

Prihatini, Dyah Aryati,_. Perbandingan Total Kemiskinan Versi Pemerintah Indonesia dan Bank Dunia dengan Peran Strategis dari Usaha Mikro untuk Pengentasan Kemiskinan. Fakultas Ekonomi Gunadarma.

Rostow, W.W. 1965. Tahap-Tahap Pertumbuhan Ekonomi, terjemahan, Paul Sitohang. Bhratara. Jakarta.

Santoso, Singgih. 2004. SPSS Parametrik. Elex Media Komputindo. Jakarta.

Sen, Amartya. 2000. Demokrasi Bisa Memberantas Kemiskinan, terjemahan, Yuliani Lipoto. Mizan, Bandung.

Sukirno, Sadono. 1985. Ekonomi Pembangunan: Proses, Masalah dan Dasar Kebijaksanaan. Jakarta.

Swasono, Sri Edi. 2002. Empowerment and Disempowerment:Membangun Ekonomi Lokal Berdasar Kekuatan Rakyat: Butir-Butir Ceramah Pada Seminar "Pengaruh Globalisasi Terhadap Kemandirian Perekonomian Indonesia”. Surabaya.

Swasono, Sri Edi. 2002. Membangun Ekonomi Rakyat: Apa Yang Mesti Kita Persiapkan. Makalah Pada Seminar "Pengaruh Globalisasi Terhadap Kemandirian Perekonomian Indonesia”. Surabaya.

Warsito, Hermawan. 1991. Pengantar Metodologi Penelitian. Gramedia. Jakarta. 